\title{
Deep-water macroalgae from the Canary Islands: new records and biogeographical relationships
}

\author{
R. J. Haroun ${ }^{1}$, W. F. Prud'homme van Reine ${ }^{2}$, D. G. Müller ${ }^{3}$, \\ E. Serrao ${ }^{4}$, R. Herrera ${ }^{1}$ \\ ${ }^{1}$ Dpto. de Biología, Universidad de Las Palmas de Gran Canaria; 35017 Las Palmas, \\ Spain \\ ${ }^{2}$ Rijksherbarium/Hortus Botanicus, University of Leiden; P.O. Box 9514, 2300 RA Leiden, \\ The Netherlands \\ ${ }^{3}$ Fakultät für Biologie der Universität Konstanz; Postfach 5560, D-78434 Konstanz, \\ Federal Republic of Germany \\ ${ }^{4}$ U.C.T.R.A., Universidade de Algarve; Campus de Gambelas, 8000 Faro, Portugal
}

\begin{abstract}
Due to the geographical location and paleobiogeography of the Canary Islands, the seaweed flora contains macroalgae with different distributional patterns. In this contribution, the biogeographical relations of several new records of deep-water macroalgae recently collected around the Canarian archipelago are discussed. These are Bryopsidella neglecta (Berthold) Rietema, Discosporangium mesarthrocarpum (Meneghini) Hauck, Hincksia onslowensis (Amsler et Kapraun) P. C. Silva, Syringoderma floridana Henry, Peyssonnelia harveyana J. Agardh, Cryptonemia seminervis (C. Agardh) J. Agardh, Botryocladia wynnei Ballantine, Gloiocladia blomquistii (Searles) R. E. Norris, Halichrysis peltata (W. R. Taylor) P. Huvé et H. Huvé, Leptofauchea brasiliensis Joly, and Sarcodiotheca divaricata W. R. Taylor. These new records, especially those in the Florideophyceae, support the strong affinity of the Canary Islands seaweed flora with the warm-temperate Mediterranean-Atlantic region. Some species are recorded for the first time from the east coast of the Atlantic Ocean, enhancing the biogeographic relations of the Canarian marine flora with that of the western Atlantic regions.
\end{abstract}

\section{INTRODUCTION}

As a result of the geographical location of the Canary Islands, their seaweed flora comprises species with different biogeographical distribution types in the Atlantic Ocean: cold-temperate, warm-temperate Mediterranean-Atlantic and tropical (Feldmann, 1946; Afonso-Carrillo \& Gil Rodríguez, 1982; Lüning, 1990; Prud'homme van Reine \& van den Hoek, 1990). These biogeographical analyses are based on the floristic inventories of the benthic marine macroalgae. These inventories, however, contain mainly supralittoral and eulittoral species, because of more intensive studies of intertidal platforms. Thus, only few sublittoral macroalgae have been reported for the Canary Islands (Børgesen 1925-30; Gil-Rodríguez \& Afonso-Carrillo, 1980; Sansón et al., 1991). Only sporadic efforts have been made to investigate the sublittoral flora, the first contributions being by Vickers (1897) and Børgesen (1938). In recent years, the extensive collections arising from the CANCAP expeditions to the Macaronesian Islands have 
added significant new data for the area (Prud'homme van Reine, 1988; Prud'homme van Reine \& van den Hoek, 1988, 1990).

In general, deep-water benthic algal communities all over the world have only occasionally been studied in detail because of methodological difficulties encountered in the sampling of such remote environments. Until now, collections for these studies have been based on dredging methods or SCUBA diving (Hiscock \& Maggs, 1984; Kajimura, 1987; Searles \& Schneider, 1987). Recently, Remote Operated Vehicles (ROV) provided with a video camera and/or collecting equipment as well as the availiability of research submersibles have enhanced studies on deep-water communities (Littler et al., 1986; Hanisak \& Blair, 1988). Nevertheless, deep-water macroalgae are still not well known.

The purpose of the present contribution is to report on several newly recorded deepwater macroalgae recently collected in the Canarian archipelago and to discuss their biogeographical relations, which may further contribute to an understanding of its seaweed flora.

\section{MATERIAL AND METHODS}

Sampling by intertidal collecting, SCUBA diving and video-aided dredging was executed at 63 stations between September-October 1991 from the German R.V. Heincke (Fig. 1). All islands of the archipelago were visited, but sampling on northern coasts of some islands and on the coasts of Gomera Island was not possible because of adverse weather conditions. Additional samples were obtained by dredging on a seamount near Fuerteventura Island (stations 53-55). The following abbreviations are used from east to west for the Canary Islands: L, Lanzarote; F, Fuerteventura; $C$, Gran Canaria; T, Tenerife; G, Gomera; P, La Palma and H, Hierro.

The collected material was sorted out on shipboard, and interesting specimens, as well as the crustose coralline algae, were preserved in $5 \%$ Formalin in seawater and stored in the dark. Most specimens were provisionally identified on board using keys, descriptions and records from published papers on marine algae for Macaronesia and adjacent areas (Børgesen, 1925-30; Taylor, 1960; Gil-Rodríguez \& Afonso-Carrillo, 1980; Lawson \& John, 1987; Afonso-Carrillo \& Sansón, 1989; Schneider \& Searles, 1991), although many additional references were used as well. Data on distribution of the collected taxa were obtained from the data matrix on Macaronesian marine algae (Prud'homme van Reine, 1988; Prud'homme van Reine \& van den Hoek, 1988, 1990). Species names are mainly arranged following the systematic approach of Wynne (1986). More than 1245 voucher specimens of 278 macroalgal species were prepared and mounted; voucher numbers correspond to the Rijksherbarium Leiden collection numbers of the CANCAP expeditions. The main voucher collection is kept in the Las Palmas de Gran Canaria University Herbarium. Duplicates of most species are deposited in the Rijksherbarium of Leiden and some in the Algarve Herbarium. Detailed studies on the collected specimens were undertaken in the laboratories in Las Palmas de Gran Canaria and in Konstanz, Germany.

Laboratory cultures were used to obtain smaller taxa not directly detectable in field collections. They were initiated by isolating millimeter-sized fragments of various substrata, such as macroalgae, shells, coralline algae, small pebbles or sand grains into polypropylene tubes with $4-\mathrm{ml}$ culture medium (sea water with PES enrichment). Upon arrival at the Konstanz laboratory, the inoculants were transferred to polystyrene Petri 


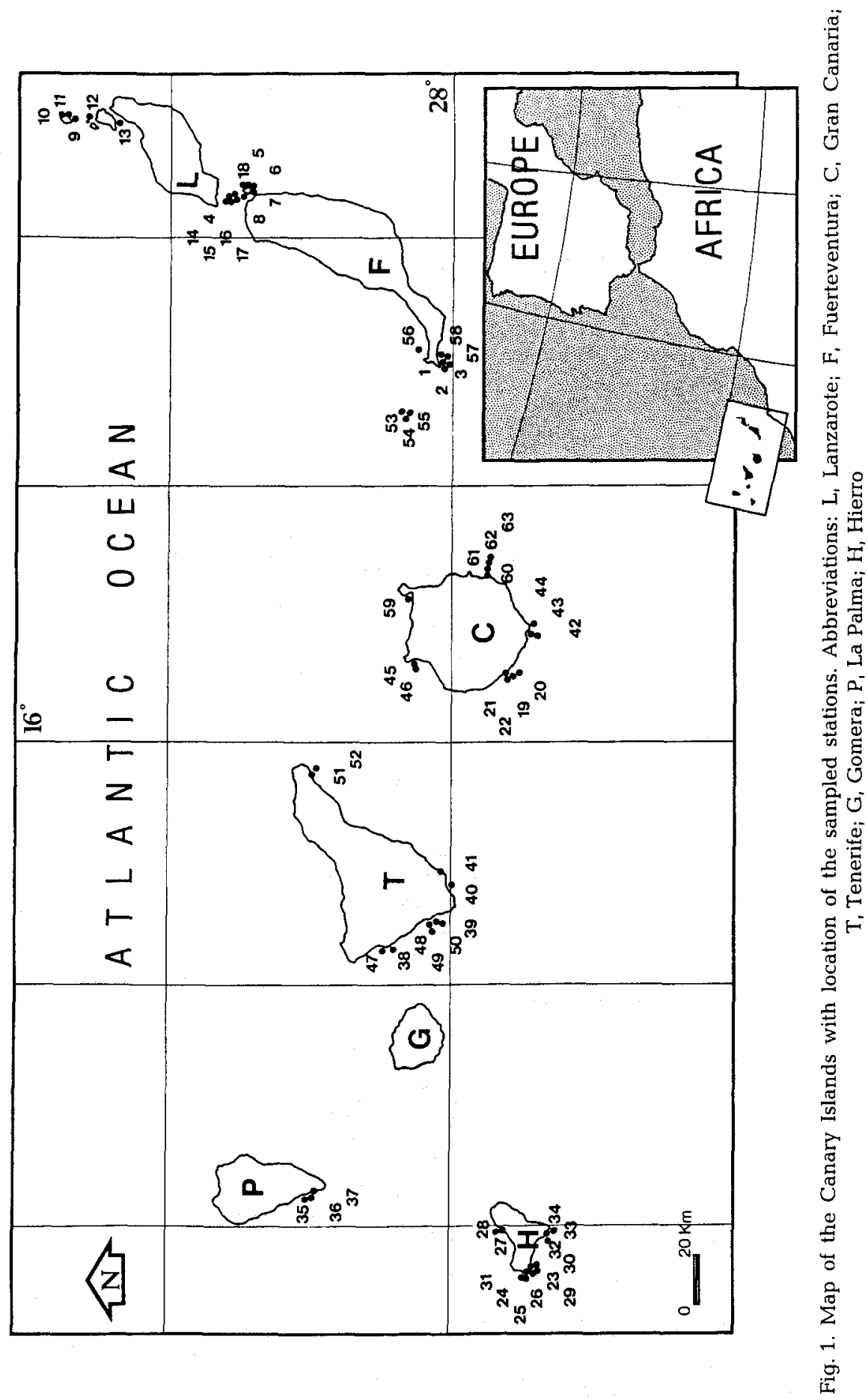


dishes and incubated at 12 or $18 \pm 1^{\circ} \mathrm{C}$ under white fluorescent light with photon fluence rates between 11 and $17 \mu \mathrm{mol} \mathrm{m} \mathrm{m}^{-2} \mathrm{~s}^{-1}$. Interesting taxa developing in such raw cultures were made unialgal by isolation of clean thallus fragments. For documentation, algal thalli were fixed and stained in acetocarmine, containing a trace amount of aniline blue, and mounted in $50 \% \mathrm{Karo}^{\circledR}$ corn syrup.

\section{RESULTS}

\section{Chlorophyta: Bryopsidaceae}

\section{Bryopsidella neglecta (Berthold) Rietema}

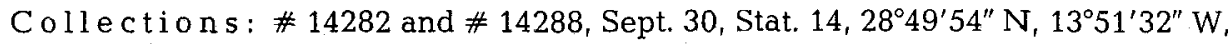
Estrecho La Bocaína between $\mathrm{L}$ and $\mathrm{F}$, depth 65-70 m; \# 14365, Sept. 30, Stat. 15, $28^{\circ} 49^{\prime} 54^{\prime \prime} \mathrm{N}, 13^{\circ} 51^{\prime} 32^{\prime \prime} \mathrm{W}$, Estrecho La Bocaína between L and F, depth 70-80 m;

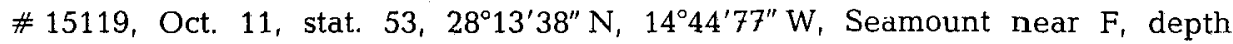
$45-50 \mathrm{~m}$; \# 15250, Oct. 11 , Stat. 56, 28 $09^{\prime} 35^{\prime \prime} \mathrm{N}, 14^{\circ} 26^{\prime} 89^{\prime \prime} \mathrm{W}$, Pta. Barlovento, F, depth $64 \mathrm{~m}$.

Small plants of a coenocytic green alga were collected as epiphytes on blades of various Halymenia species. They were originally identified by us as Bryopsis halymeniae Berthold. Rietema (1972) demonstrated that this is a stage in the life cycle of Derbesia neglecta Berthold. The correct name was later changed to Bryopsidella neglecta (Rietema, 1975). All plants we collected were sterile (Fig. 2). Later, B. neglecta plants

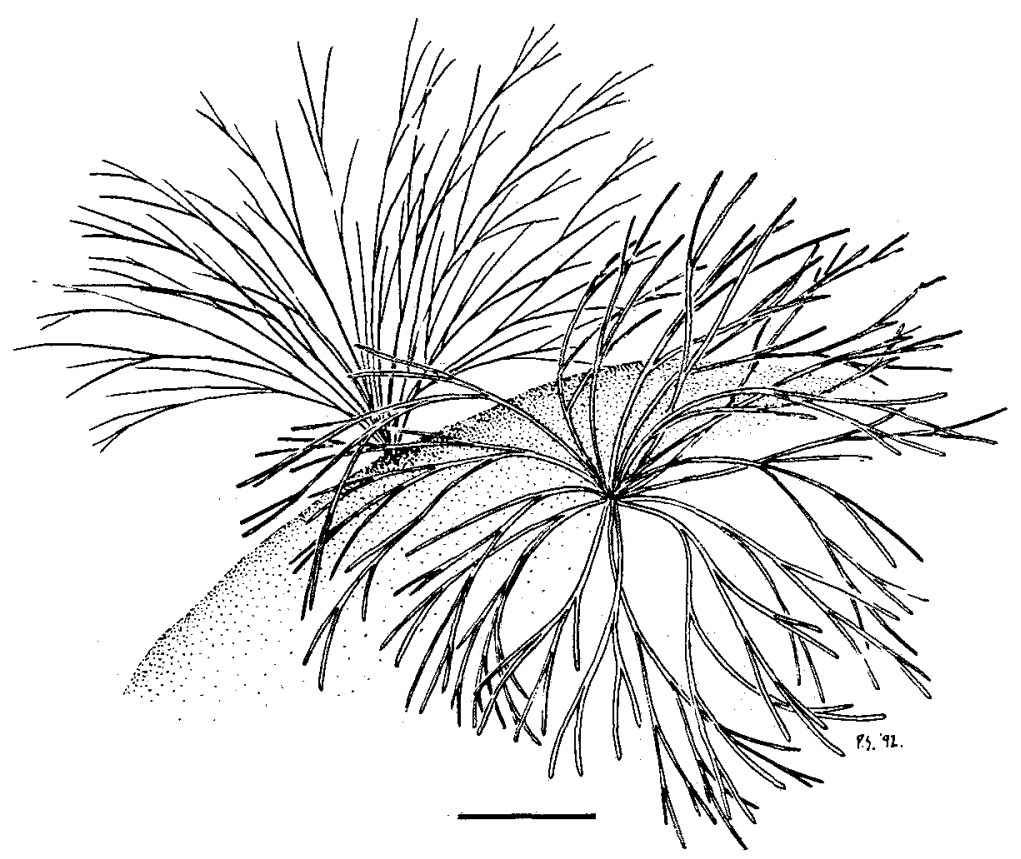

Fig. 2. Bryopsidella neglecta (Berthold) Rietema. General morphology. Scale: $5 \mathrm{~mm}$ 
were also obtained in culture from spores of field-collected D. neglecta specimens from the same depth range.

World distribution: Mediterranean Sea and Atlantic coast of Morocco.

Notes on biogeography: These records represent an extension of the known distribution area of this species (Fig. 12). B. neglecta appeared in our samples from between 45-80 m depth on Halymenia blades; this is the deepest known record for this species in its distributional range. As D. neglecta it was reported for T (Børgesen, 1925), but as a tide pool plant.

\section{Phaeophyta: Ectocarpaceae}

Hincksia onslowensis (Amsler et Kapraun) P. C. Silva

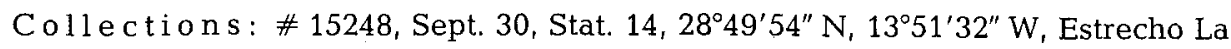
Bocaína between $\mathrm{L}$ and $\mathrm{F}$, depth 65-70 $\mathrm{m}$; \# 15249, Oct. 8, Stat. 46, 28 $09^{\prime} 12^{\prime \prime} \mathrm{N}$, $15^{\circ} 42^{\prime} 72^{\prime \prime}$ W, Sardina del Norte, C, depth $30-40 \mathrm{~m}$.

Filamentous, uniseriate ectocarpoid thalli up to $5 \mathrm{~cm}$ long, were found entangled with other species. Basal filaments are sparsely branched, whereas apical filaments are profusely branched. Plurilocular sporangia, sessile or on one- to several-celled pedicels, are laterally attached. Additional features such as cell dimensions and chloroplast morphology allowed us to identify these specimens as Hincksia onslowensis, a species recently described from North Carolina deep-water flora (Amsler \& Kapraun, 1985, as Giffordia onslowensis). Plants were isolated from inoculants of Syringoderma floridana Henry and Sporochnus bolleanus Montagne fragments.

In older cultures, plants formed abundant lateral outgrowths of $2-5$ cells in length, which extend at right angles and have a rhizoidal character. This feature and the presence of unilocular sporangia are shared with Hincksia sordida (Harvey) P. C. Silva, which is a related taxon reported from Tasmania and southern Australia (Womersley, 1987, as Giffordia sordida). An isolate, collected in 1991 from the coast of Chile, shows intermediate characteristics, well-developed pseudohairs and unilocular sporangia (Müller, unpubl.). A comparative culture study with isolates from the type locality of each taxa, as well as the Canarian and Chilean populations, is needed to clarify the relationship between these geographically separated entities.

World distribution: western Atlantic Ocean: North Carolina and Georgia. As Hincksia sordida in the Pacific Ocean: Tasmania, southern Australia and northern Chile.

Notes on biogeography: Hincksia onslowensis is a brown alga first described from the North Carolina continental shelf and later reported from nearby areas. Our collections, also as deep-water plants at depths of 30-70 m, represent new records and greatly extend its distributional range to the Eastern Atlantic Ocean. Its area of distribution is rather similar to that figured for Syringoderma floridana Henry and Gloiocladia blomquistii (Searles) R. E. Norris (Fig. 12).

\section{Choristocarpaceae}

Discosporangium mesarthrocarpum (Meneghini) Hauck

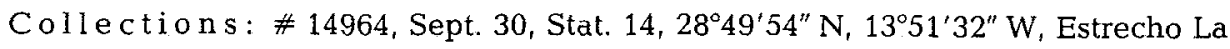
Bocaina between $L$ and $F$, depth $65-70 \mathrm{~m}$; \# 14450, Sept. 30, Stat. 17, 28 49 $79^{\prime \prime} \mathrm{N}$, 

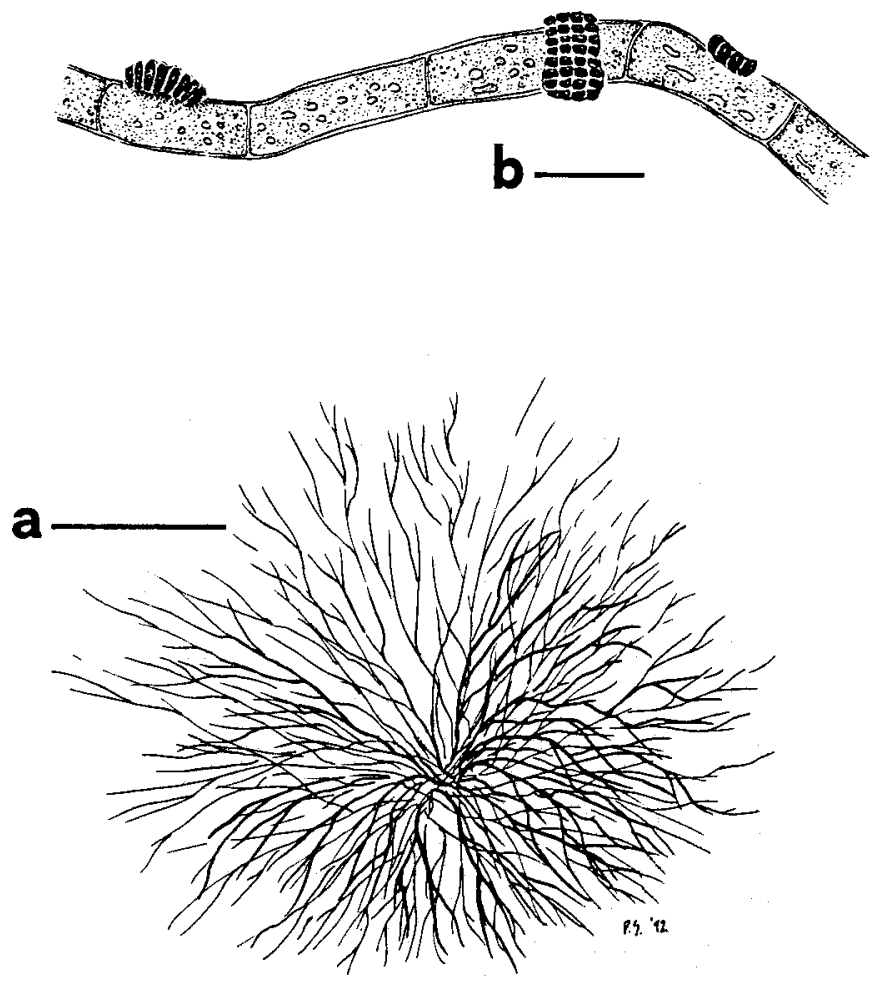

Fig. 3. Discosporangium mesarthrocarpum (Meneghini) Hauck. a: General morphology; b: plurilocular sporangia. Scale: $2 \mathrm{~mm}$ (a) and $50 \mu \mathrm{m}$ (b)

$13^{\circ} 40^{\prime} 20^{\prime \prime} \mathrm{W}$, Estrecho La Bocaina between $\mathrm{L}$ and $\mathrm{F}$, depth $30-40 \mathrm{~m}$; \# 14971, Oct. 8 , Stat. $46,28^{\circ} 09^{\prime} 12^{\prime \prime} N, 15^{\circ} 42^{\prime} 72^{\prime \prime}$ W, Sardina del Norte, C, depth $30-40 \mathrm{~m}$.

Filamentous, brownish thalli, 2-7 mm in length, were collected entangled with other species. Several characters, as, for example, the presence of discoid lateral plurilocular sporangia, branching pattern and cell morphology, were used to identify these specimens as $D$. mesarthrocarpum, a rare brown alga with uncertain phylogenetic affinities (Fig. $3 a, b)$.

World distribution: Mediterranean Sea, Adriatic Sea, eastern Atlantic Ocean: Madeira Archipelago, and southern Australia.

Notes on biogeography: $D$. mesarthrocarpum was described from the Adriatic in the last century, and has since been collected in other Mediterranean localities, as well as in Southern Australia, where it may have been introduced (Womersley, 1987). In addition, Audiffred \& Prud'homme van Reine (1985), collected it at Porto Santo, Madeira Archipelago (north of the Canary Islands). Our collections, between Lanzarote and Fuerteventura Islands at 30-70 m depth, extend its southern limit to the Canarian Archipelago and confirm its presence in the Macaronesian Islands (Fig. 12). 


\section{Syringodermataceae}

\section{Syringoderma floridana Henry}

Collections: \# 14271 , Sept. 30 , Stat, $14,28^{\circ} 49^{\prime} 54^{\prime \prime}$ N, $13^{\circ} 51^{\prime} 32^{\prime \prime}$ W, Estrecho La Bocaína between $L$ and $F$, depth $65-70 m_{\text {; }}$ \# 14350, Sept. 30, Stat. 15, 28 $49^{\prime} 54^{\prime \prime} \mathrm{N}$, $13^{\circ} 51^{\prime} 32^{\prime \prime}$ W, Estrecho La Bocaína between L and F, depth 70-80 m; \#14396, Sept.

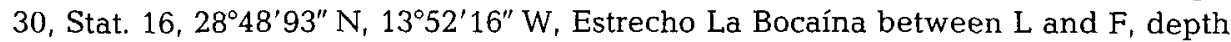

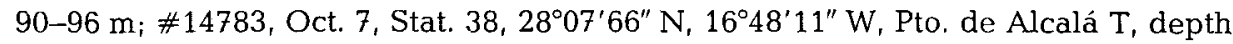

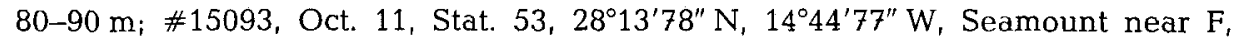
depth $45-50 \mathrm{~m}_{\text {; }} \# 15144$, Oct. 11 , Stat. $56,28^{\circ} 09^{\prime} 35^{\prime \prime} \mathrm{N}, 14^{\circ} 26^{\prime} 89^{\prime \prime} \mathrm{W}$, Pta. Barlovento, $\mathrm{F}$, depth $64 \mathrm{~m}$.

In several dredge hauls, small brown algae identified as $S$. floridana were collected. The thallus is flabellate, up to $1.5 \mathrm{~cm}$ long, monostromatic, with distinct marginal growth, attached to the rocky substrate by rhizoidal filaments and covered by sessile unilocular sporangia (Fig. 4a, b, c).

World distribution: western Atlantic Ocean: eastern Florida.
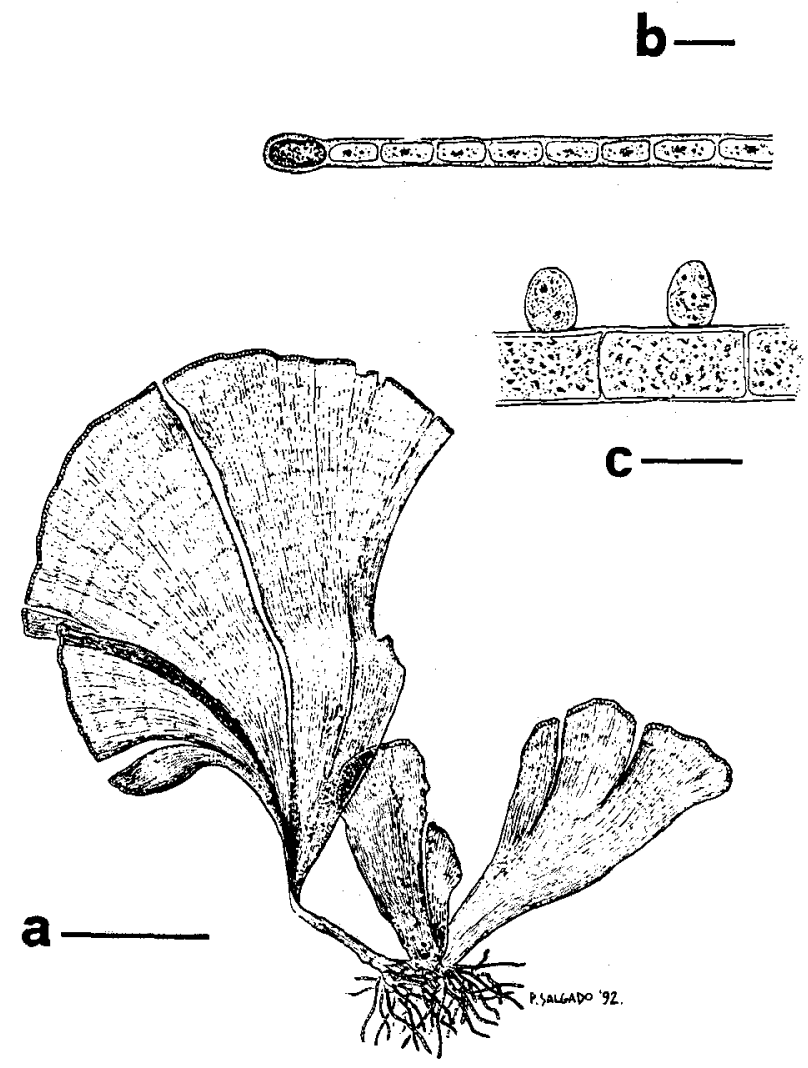

Fig. 4. Syringoderma floridana Henry. a: General morphology; b: T. S. near the margin; c: plurilocular sessile sporangia. Scale: $3 \mathrm{~mm}(\mathrm{a})_{;}, 100 \mu \mathrm{m}(\mathrm{b})$ and $50 \mu \mathrm{m}$ (c) 
Notes on biogeography: This species is a typical member of the deep-water flora of the eastern Florida continental shelf. Until now, collections of specimens tentatively assigned to this genus were recorded from Canarian and other Macaronesian islands (Oosterbaan, Univ. of Leiden, unpublished report), but an absence of fertile structures did not allow exact identification. During the present expedition, several samples contained some fertile material. Hence its presence in the eastern Atlantic Ocean is confirmed, greatly extending its known distributional range (Fig. 12).

\section{Rhodophyta: Peyssonneliaceae}

Peyssonnelia harveyana J. Agardh

Collections: \# 15107, Oct. 11, Stat. 15107, $28^{\circ} 13^{\prime} 38^{\prime \prime}$ N, $14^{\circ} 44^{\prime} 77^{\prime \prime}$ W, Seamount

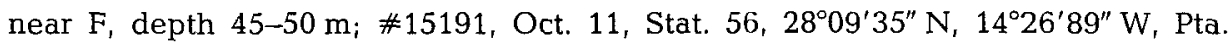
Barlovento, F, depth $64 \mathrm{~m}$.

Specimens of a dark-red crust identified as $P$. harveyana were collected from the seamount near $F$. The thallus was strongly adherent to the substratum except at its margins, entire or lobed, with a verrucose and radially striated surface (Fig. $5 \mathrm{a}, \mathrm{b}$ ). In some specimens, irregular sori with cruciate tetrasporangia were observed.
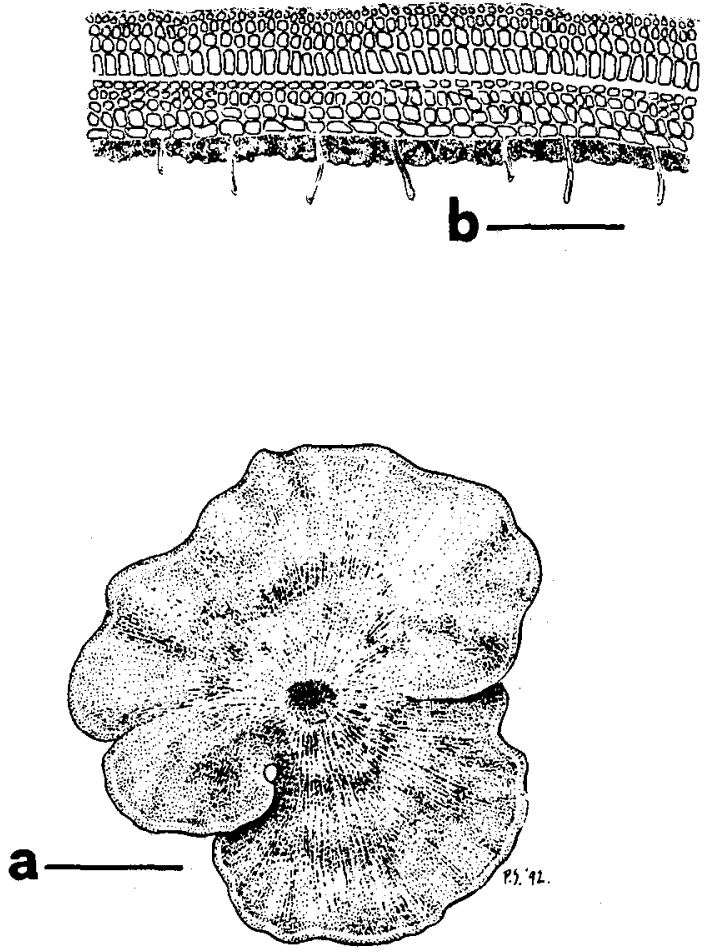

Fig. 5. Peyssonnelia harveyana J. Agardh. a: General morphology; b: T.S. of the thallus. Scale: $10 \mathrm{~mm}$ (a) and $300 \mu \mathrm{m}$ (b) 
World distribution: Mediterranean Sea, eastern Atlantic Ocean: British Isles to Portugal.

Notes on biogeography: Previous records of epilithic or ephiphytic Peyssonnelia harveyana are all from the upper sublittoral to $12 \mathrm{~m}$, not from such depths as found during the present expedition. The distribution area of this species includes the Mediterranean Sea, and the coasts of Portugal and the British Isles. Our records extend the distributional range of the species further to the south (Fig. 12).

\section{Halymeniaceae}

Cryptonemia seminervis (C. Agardh) J. Agardh

Colle ction s: \# 14375, Sept. 30 , Stat. 15, 28 $49^{\prime} 54^{\prime \prime}$ N, $13^{\circ} 51^{\prime} 32^{\prime \prime}$ W, Estrecho La Bocaína between $\mathrm{L}$ and $\mathrm{F}$, depth 70-80 $\mathrm{m}_{\mathrm{i}} \#$ 15193, Oct. 11, Stat. 56, 28 $09^{\prime} 35^{\prime \prime} \mathrm{N}$, $14^{\circ} 26^{\prime} 89^{\prime \prime} \mathrm{W}$, Pta. Barlovento, $\mathrm{F}$, depth $64 \mathrm{~m}$.

In two dredge samples from depths between $60-80 \mathrm{~m}$, several fleshy, red algae were collected. Thalli were rose-red, up to $5 \mathrm{~cm}$ in length, arising from a small discoidal holdfast, with a short terete stipe of $0.8 \mathrm{~mm}$ diameter in basal parts, expanding into fanshaped blades with cuneate bases, in which the stipes extend as evanescent midribs. Margins were irregular, with some proliferations (Fig. 6a, b).

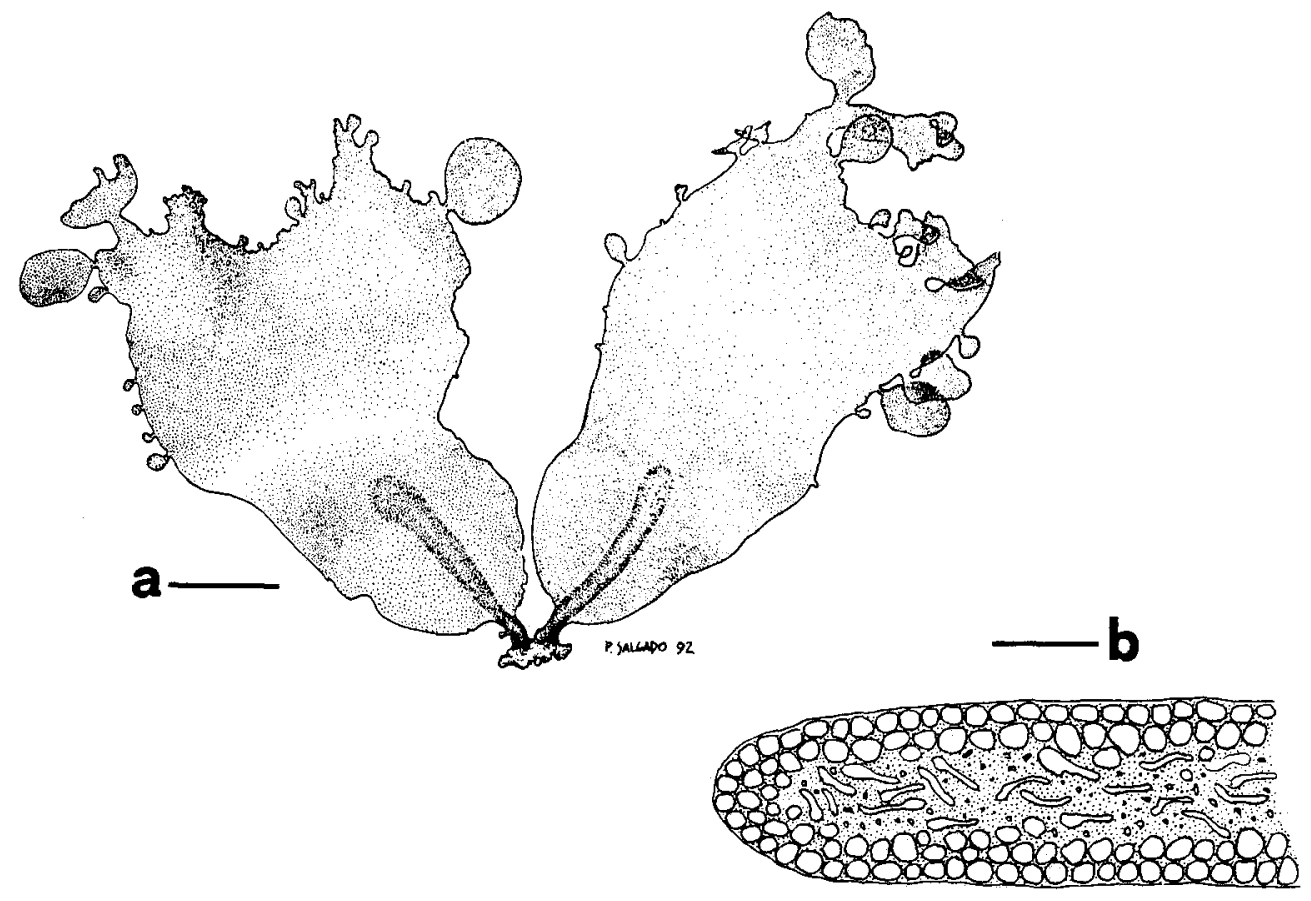

Fig. 6. Cryptonemia seminervis (C. Agardh) J. Agardh. a: General morphology; b: T. S. of the thallus. Scale: $5 \mathrm{~mm}$ (a) and $30 \mu \mathrm{m}$ (b) 
Following Price et al. (1986), Cryptonemia seminervis and C. luxurians (C. Agardh) J. Agardh are treated here as a single species, with $C$. seminervis as the earliest available name.

Cryptonemia lomation Berthold, reported by Børgesen (1938) from a deep-water collection near $\mathrm{C}$, was also encountered during this expedition, as well as C. crenulata (J. Agardh) J. Agardh, which was recently reported for T (Gil-Rodriguez et al., 1985) as an intertidal species. Apart from other morphological differences, both species lack the conspicuous midrib observable in $C$. seminervis.

World distribution: As C. seminervis, this species is reported in the East Atlantic ocean, from the Scilly Isles in south-western Britain (Maggs \& Guiry, 1987), down to southern Spain and the Atlantic coast of Morocco; it is also known from West Africa. It has also been reported as C. Iuxurians from several localities of the tropical and warmtemperate regions of the western Atlantic Ocean.

Notes on biogeography: This new record fills the gap in the distributional range of this species along the eastern Atlantic coast, resulting in a new distributional range which includes the tropical and warm-temperate regions of both sides of the Atlantic Ocean (Fig. 12).

\section{Rhodymeniaceae}

\section{Botryocladia wynnei Ballantine}

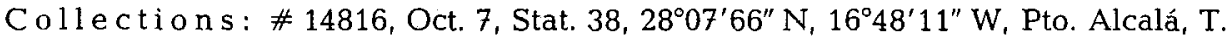

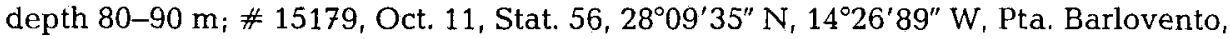
$\mathrm{F}$, depth $64 \mathrm{~m}$.

This small, red alga was identified as $B$. wynnei due to its external morphology with a short stipe and the presence of 1-7 gland cells protruding into the inner cavity. The cortex is incomplete (Fig. $7 a, b, c)$.
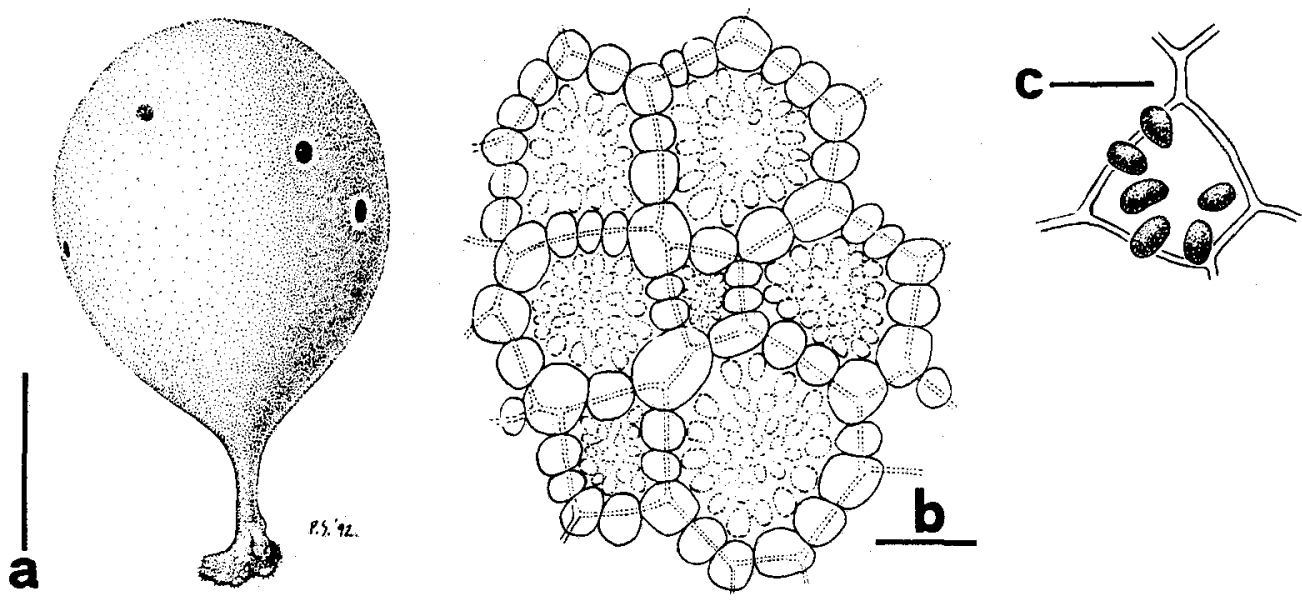

Fig. 7. Botryocladia wynnei Ballantine. a: General morphology; b: surface view of outer wall of a vesicle; c: inner vesicle wall showing a gland-supporting cell with 6 gland cells. Scale: 5 mm (a); $25 \mu \mathrm{m}(\mathrm{b})$ and $50 \mu \mathrm{m}(\mathrm{c})$ 
Other Botryocladia species, namely $B$. boergesenii Feldmann, B. chiajeana (Meneghini) Kylin and Botryocladia occidentalis (Børgesen) Kylin were also collected during this cruise, but their general morphology and internal structures differed from $B$. wynnei (Ballantine, 1985). Another related species is B. lawsonii John, which often has a branched stipe and vesicles which are much longer (Lawson \& John, 1987).

World distribution: western Atlantic Ocean: Puerto Rico and North Carolina.

Notes on biogeography: $B$. wynnei is a deep-water species first described from Puerto Rico and later reported from the continental shelf of North Carolina. Our records represent an extension of its distributional range to the eastern Atlantic Ocean (Fig. 12).

\section{Gloiocladia blomquisti (Searles) R. E. Norris}

Collections: \#15160, Oct. 11, Stat. $54,28^{\circ} 11^{\prime} 53^{\prime \prime} N, 14^{\circ} 46^{\prime} 11^{\prime \prime}$ W, Seamount

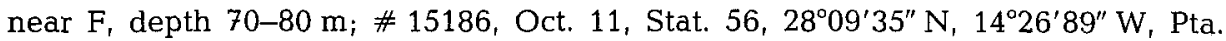
Barlovento, F, depth $64 \mathrm{~m}$.

Two samples of $G$. blomquistii were collected near F. The thallus was creeping, dichotomously and irregularly branched, with irregular and proliferous margins. The internal structure is composed of one layer of large medullary cells surrounded by a cortex of several layers of small pigmented cells (Fig. 8a, b).

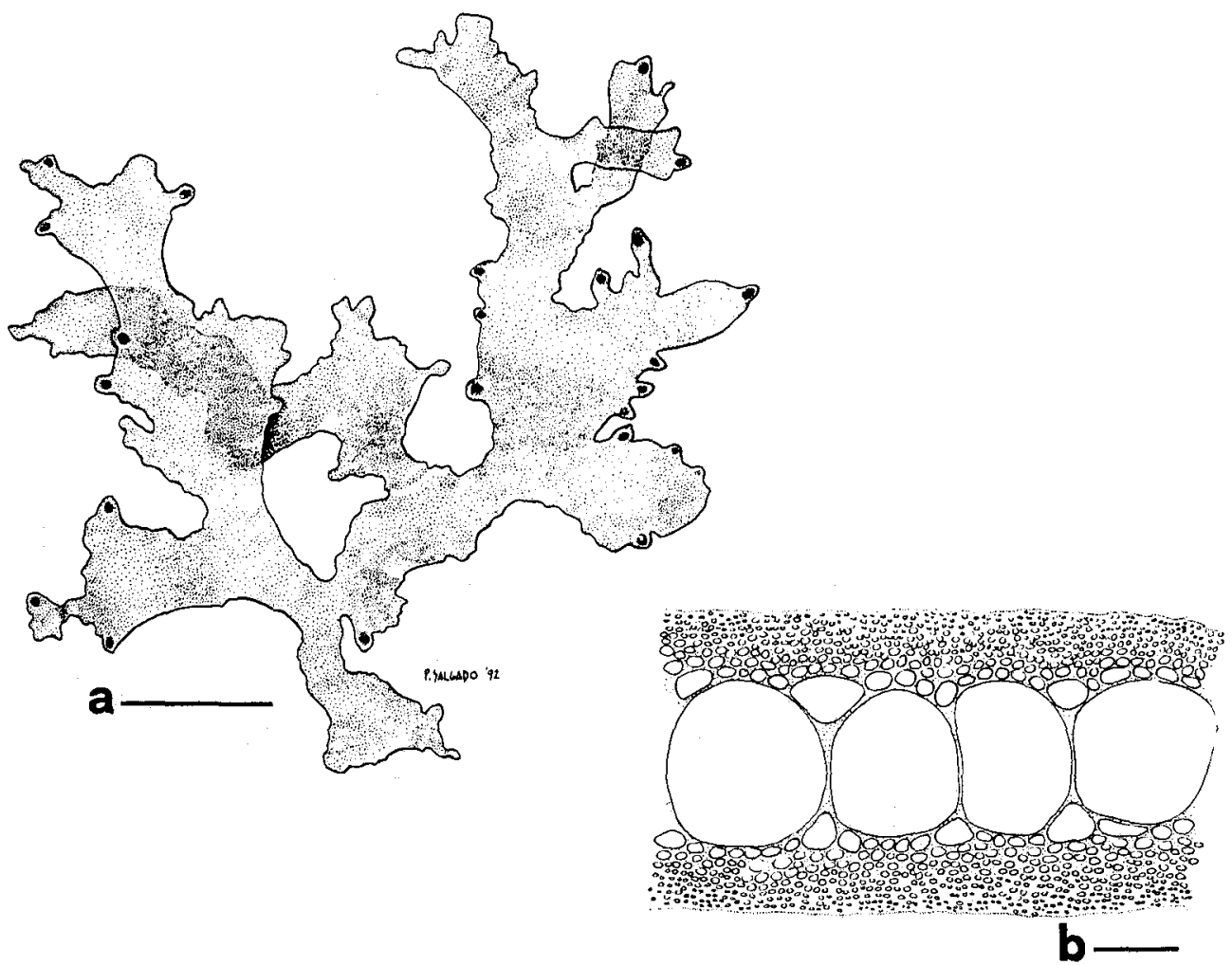

Fig. 8. Gloiocladia blomquistii (Searles) R. E. Norris. a: General morphology; b: T. S. of the thallus. Scale: $5 \mathrm{~mm}$ (a) and $100 \mu \mathrm{m}(\mathrm{b})$ 
World distribution: western Atlantic Ocean: eastern Florida and North Carolina.

Notes on biogeography: The genus Gloiocladia sensu Norris (1991) is a deep-water genus with a disjunct distribution around the Indo-Pacific and Atlantic Oceans. On the continental shelves of eastern Florida and North Carolina, three Gloiocladia species are known; two of these have been collected for the first time from deep-water habitats in the Canary Islands. In this contribution, only the material assigned to G. blomquistii is reported (Fig. 12). A similar species is tentatively identified as Gloiocladia atlantica (Searles) R. E. Norris because of its pinnate habit; but that sample needs further study.

Halichrysis peltata (W. R. Taylor) P. Huvé et H. Huvé

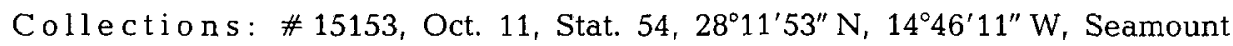
near F, depth $70-80 \mathrm{~m}_{\text {; }}$ \# 15189, Oct. 11, Stat. 56, $28^{\circ} 09^{\prime} 35^{\prime \prime} \mathrm{N}, 14^{\circ} 26^{\prime} 89^{\prime \prime} \mathrm{W}$, Pta. Barlovento, $F$, depth $64 \mathrm{~m}$.

Small plants assigned to $H$. peltata were collected growing attached to the substratum by small discoidal holdfasts. The thallus is shortly stipitate with irregular or lobed blades, fleshy, up to $2.5 \mathrm{~cm}$ tall and with an internal structure of very large inner medullary cells and a cortex of 2-4 layers of small pigmented cells (Fig. 9a, b).

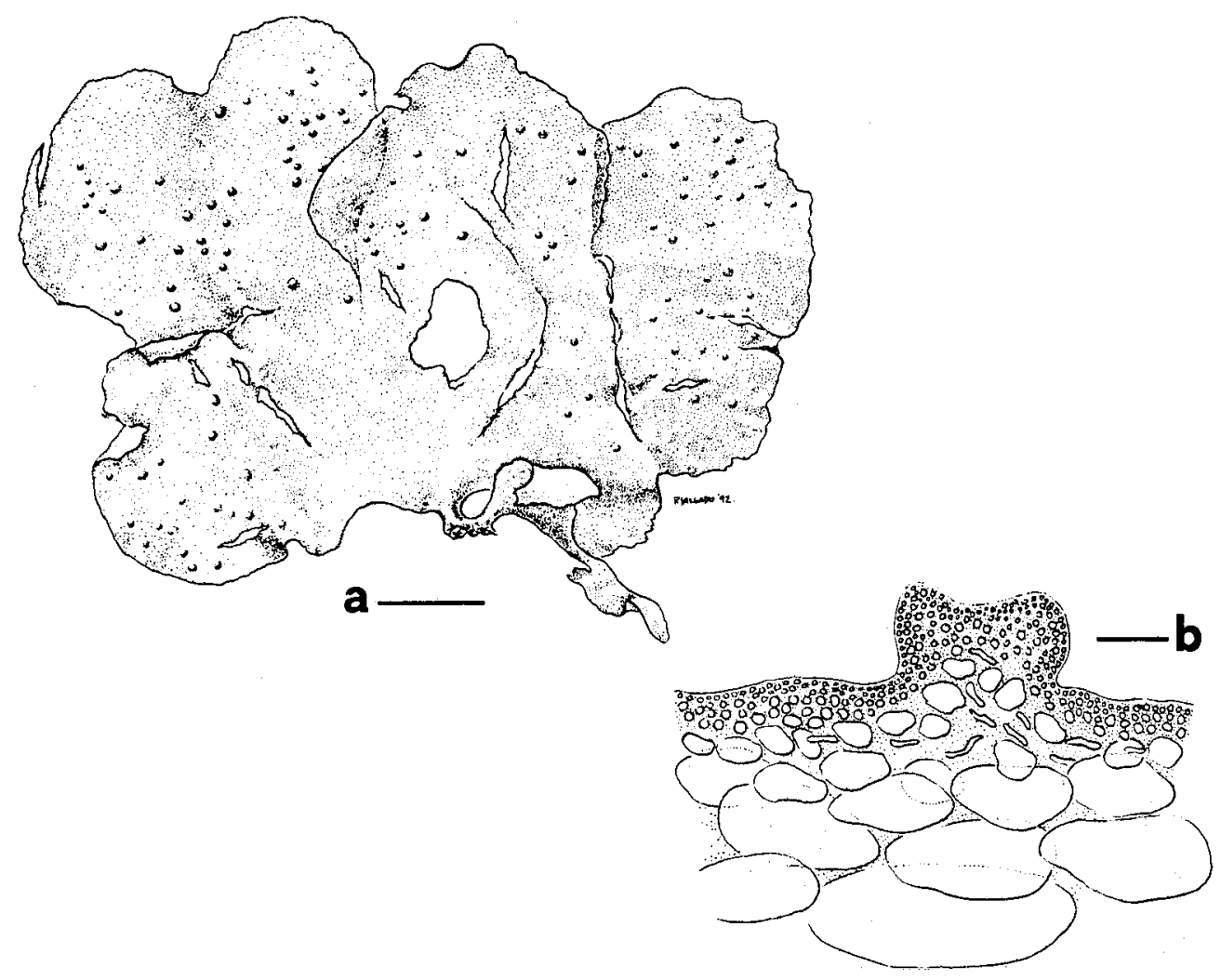

Fig. 9. Halichrysis peltata (W. R. Taylor). P. Huvé et H. Huvé, a: General morphology; b: T. S. of the thallus partly through a cystocarp. Scale: $5 \mathrm{~mm} \mathrm{(a)} \mathrm{and} 50 \mu \mathrm{m}$ (b) 
Another Halichrysis species, H. depressa (J. Agardh) Bornet is reported for the West African coasts as an intertidal and rarely sublittoral species occurring down to depths of 8-16 m (Lawson \& John, 1987). It is also recorded at similar depths in the Mediterranean Sea. This latter species differs from our specimens in general morphology as well as in its internal structure, which gives rise to some doubts about the taxonomic status of the genus. See also P. Huvé \& H. Huvé (1977) and R. E. Norris (1991).

World distribution: Tropical and subtropical coasts of the western Atlantic Ocean.

Notes on biogeography: The present species was first described as Fauchea peltata by Taylor (1942) from Tortuga Island (Venezuela), as a deep-water macroalga collected at $40 \mathrm{~m}$. It is now known in other parts of the tropical and warm-temperate regions of the western Atlantic Ocean. Our specimens represent a new record for the eastern Atlantic Ocean (Fig. 12).

\section{Leptofauchea brasiliensis Joly}

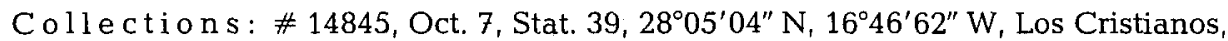
$T$, depth 90-110 m.

In a dredge sample from depths between 90-110 m, specimens of a small red alga with fleshy lanceolate blades were collected. Its internal structure agrees with that of $L$. brasiliensis, with a medullary layer of large hyaline cells surrounded by 1-2 incomplete layers of medium-sized cells and a cortex with only one layer of small pigmented cells (Fig. 10a, b).

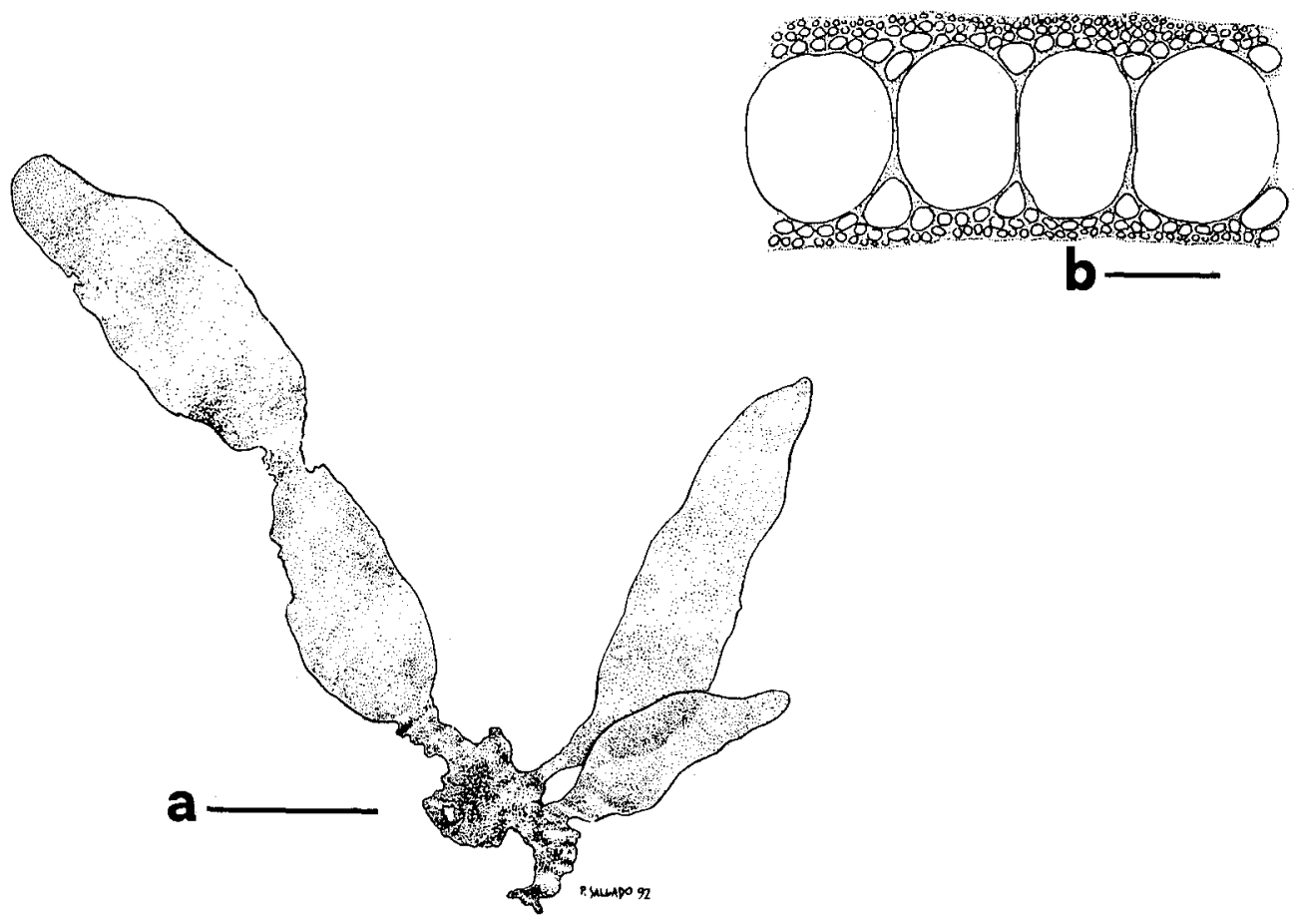

Fig. 10. Leptofauchea brasiliensis Joly, a: General morphology; b: T. S. of the thallus. Scale $5 \mathrm{~mm}$ (a) and $100 \mu \mathrm{m}(\mathrm{b})$ 
World distribution: western Atlantic Ocean: Brazil, Curaçao, eastern Florida and North Carolina.

Notes on biogeography: This species, described as a deep-water plant from the Brazilian coast by Joly (1957), has been reported as a member of the deep-water flora from the continental shelves of eastern Florida and North Carolina. Its occurrence near T represents a new record for the eastern Atlantic Ocean (Fig. 12).

\section{Solieriaceae}

\section{Sarcodiotheca divaricata W. R. Taylor}

Collections: \#15125, Oct. 11 , Stat. $53,28^{\circ} 13^{\prime} 38^{\prime \prime}$ N, $14^{\circ} 44^{\prime} 77^{\prime \prime}$ W, Seamount near $F$, depth $45-50 \mathrm{~m}$.

The thallus of this alga is erect, up to $2 \mathrm{~cm}$ in length, dichotomously divided and pink-red in colour. Its internal structure consists of a medulla of hyaline filaments embedded in a gelatinous matrix, bounded by two layers of large, rounded, colourless cells and a cortex of two layers of small pigmented cells (Fig. 11a, b).

World distribution: Pacific Ocean: Galapagos Islands; western Atlantic Ocean: eastern Florida and North Carolina.

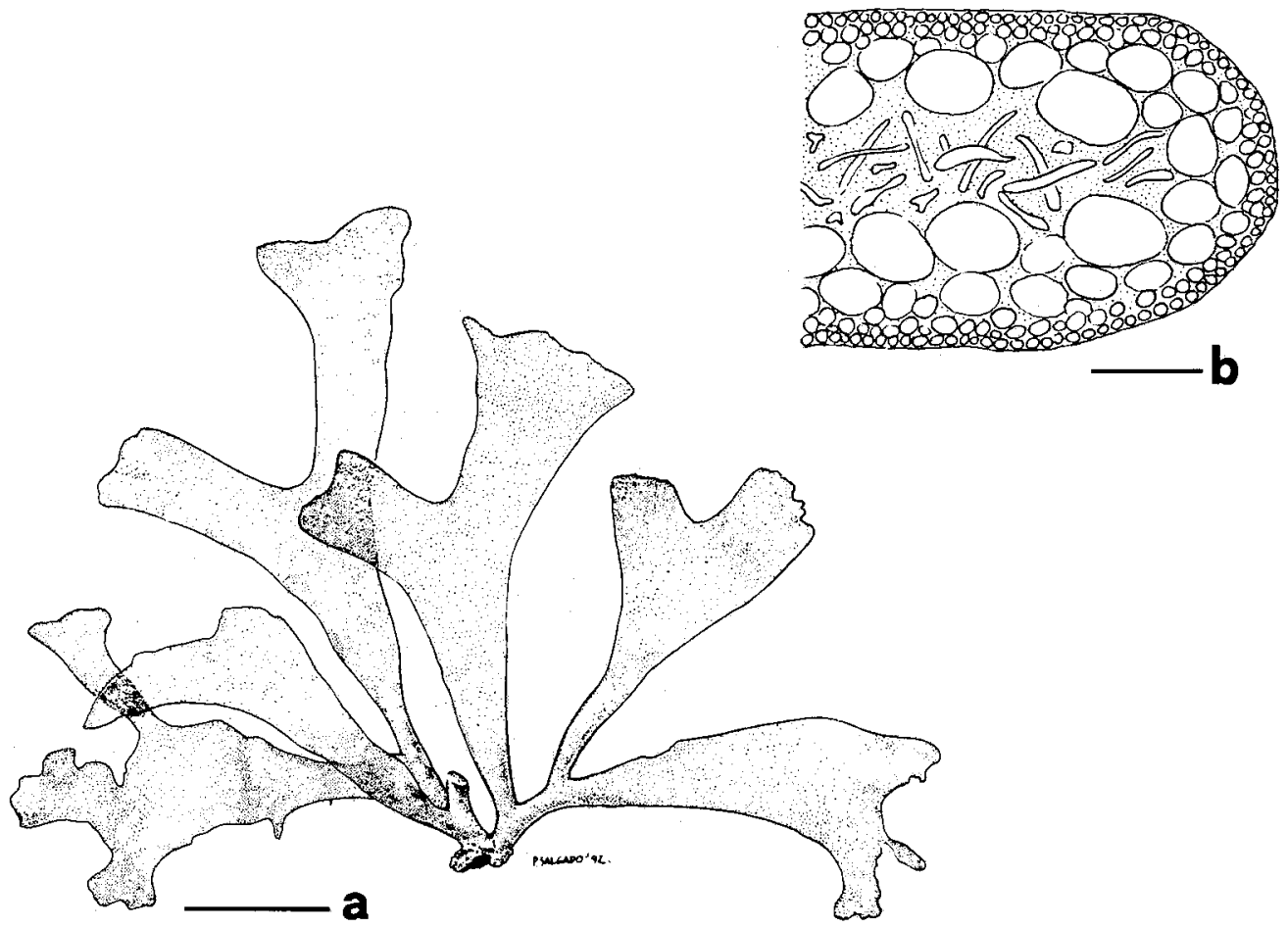

Fig. 11. Sarcodiotheca divaricata W. R. Taylor. a: General morphology; b: T. S. of the thallus. Scale: $5 \mathrm{~mm}$ (a) and $100 \mu \mathrm{m}(\mathrm{b})$ 
Notes on biogeography: This species was first described from deep water off the Galapagos Islands in the Pacific Ocean (W. R. Taylor, 1945). Subsequently, it was found on the continental shelves of eastern Florida and North Carolina. In the present paper it is recorded for the first time, as a deep-water plant, in the eastern Atlantic Ocean (Fig. 12).

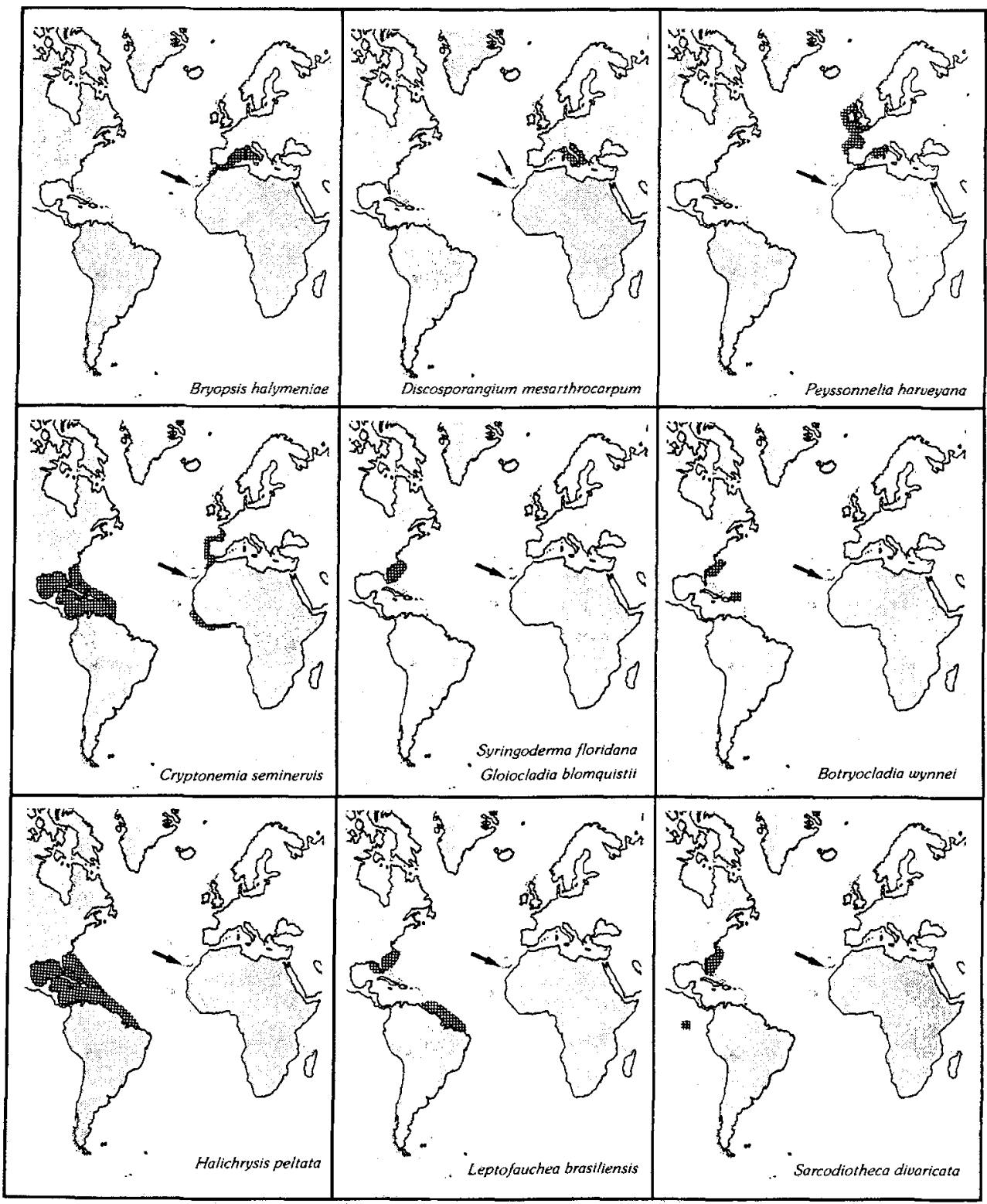

Fig. 12. Distributional maps of newly recorded species in the Canary Islands. Hatched area: previously known area; thick arrow: Canary Islands; thin arrow: Madeira Archipelago 


\section{DISCUSSION}

The Canary Islands are young volcanic islands formed less than 20 million years ago $(20 \mathrm{Ma})$, and are separated by deep trenches. However, the easternmost islands, Lanzarote and Fuerteventura, may have originated as fragments of the African plate, which drifted to deeper waters. The richness of the Canary marine algal flora is thought to be the result of paleoclimatic events, its specific geographical position, and the lasting availability of many different microclimates along its coasts (Afonso-Carrillo \& GilRodríguez, 1982; Prud'homme van Reine \& van den Hoek, 1990).

Most of the studies on seaweed biogeography are devoted to the analysis of paleo- or present distribution areas of intertidal and shallow-water macroalgal species. During the last 20 years, a rich deep-water seaweed flora was discovered on scattered offshore reefs in between North Carolina and eastern Florida. More stable environmental conditions prevail in such deep habitats, making them suitable for the survival of several tropical to warm-temperate species (Schneider \& Searles, 1973; Searles, 1984, 1987; Hanisak \& Blair, 1988). The more constant and moderate temperature conditions in deep-water environments allow the survival of species on both sides of the Atlantic Ocean. Our findings also extend the depth ranges for species previously listed only from shallowwater, such as Peyssonnelia harveyana and Bryopsidella neglecta, which suggests that these macroalgae are only able to survive in deep-water habitats when they reach their latitudinal limits. A similar phenomenon was reported by Schneider \& Searles (1973) for North Carolina offshore macroalgae with a Caribbean origin. The deep-water environment serves as a safe place and is also a refuge for many groups of animals, such as monoplacophorans and stalked crinoids, that in more ancient times were common in shallow water (Vermeij, 1980). The persistence of these groups can be attributed to the fact that in the deep sea, no mass extinction events occurred as they did in shallow waters during colder periods (Vermeij, 1987; Breeman, 1990). Besides, many deep-water macroalgae show physiological and morphological adaptations for survival under the special conditions of deep-water habitats (Littler et al., 1986; Lüning, 1990).

The new distributional records reported here support the hypothesis that the deepwater flora of the Canary Islands is closely related to the warm-temperate western Atlantic flora (especially Hincksia onslowensis, Syringoderma floridana, Gloiocladia blomquistii, Leptofauchea brasiliensis and Sarcodiotheca divaricata) as well as to the W. Mediterranean flora (especially $B$. neglecta, Discosporangium mesarthrocarpum and $P$. harveyana). The distributional range of Sarcodiotheca divaricata can be explained by the rather recent closure of the Panama Isthmus (3.1-3.5 Ma) and illustrates a close affinity between the marine biota of both coasts of Central America (Vermeij, 1980; Lüning, 1990).

A long dispersal range for deep-water seaweeds is rather difficult to accept; the likelihood of deep-water species becoming part of a drifting seaweed raft is rather small (van den Hoek, 1987; Searles \& Schneider, 1987; Lüning, 1990). Furthermore, glaciation periods, with temperatures a few centigrades lower than today; were sufficient to shift the northern lethal boundaries of some strictly subtropical or tropical-to-subtropical species to the south of the Macaronesian Islands sensu stricto (Madeira, Salvages and Canaries). Therefore, the new distributional patterns of the deep-water species reported here may support the vicariance hypothesis already proposed by Prud'homme van Reine \& van den 
Hoek (1990) for the seaweed flora of the Macaronesian Islands. The new records suggest a closer affinity between deep-water floras present in offshore reefs or continental shelves of both sides of the Atlantic (Searles, 1984; Hanisak \& Blair, 1988). Furthermore, Fredericq et al. (1993) reported some new records of subtidal macroalgae from the Azores Islands, mostly with a tropical eastern Atlantic (West African) or Mediterranean distribution range. These findings can also be explained in the framework of a Tethyan remnants hypothesis, that is, vicariant floras occupying the western and eastern coasts of the Atlantic Ocean (Prud'homme van Reine \& van den Hoek, 1990).

Additional research is needed, both at floristic and physiological levels, to increase our understanding of the biogeographical relationships of the deep-water floras present in the Atlantic Ocean.

Acknowledgements. This paper is based on the collections made during an expedition of the R.V. Heincke of the Biologische Anstalt Helgoland, Hamburg. We are grateful to Dr. K. Lüning and Dr. G. Gassmann (B.A.H., Hamburg), who organized this expedition, and to the skilled efforts of the captain and crew of the ship.

\section{LITERATURE CITED}

Afonso-Carrillo, J. \& Gil-Rodríguez, M. C, 1982. Aspectos biogeográficos de la flora ficológica marina de las Islas Canarias. - Actas 2. Simp. ibér. Estud. Bentos mar., 3, 41-48.

Afonso-Carrillo, J. \& Sansón, M., 1989. Clave ilustrada para la determinación de los macrófitos marinos bentónicos de las Islas Canarias. Dpt. Biol. Veg. Univ, La Laguna, La Laguna, 55 pp.

Amsler, C. D. \& Kapraun, D. F., 1985. Giffordia onslowensis sp. nov. (Phaeophyceae) from the Northern Carolina continental shelf and the relationship between Giffordia and Acinetospora. J. Phycol, 21, 94-99.

Audiffred, P. A. J. \& Prud'homme van Reine, W. F., 1985. Marine algae of tha do Porto Santo and Deserta Grande (Madeira Archipelago). - Bolm Mus. munic. Funchal 37, 20-51.

Ballantine, L., 1985. Botryocladia wynnei sp. nov, and B. spinulifera (Rhodymeniales, Rhodophyta) Taylor \& Abbott from Puerto Rico. - Phycologia, 24, 199-204.

Børgesen, F., 1925. The marine algae of Canary Islands specially from Teneriffe and Gran Canaria. I. Chlorophyceae. - Biol. Meddr 5 (3), 1-123.

Børgesen, F., 1926. The marine algae of Canary Islands specially from Teneriffe and Gran Canaria. II. Phaeophyceae. - Biol. Meddr 6 (2), 1-112.

Børgesen, F., 1927. The marine algae of Canary Islands specially from Teneriffe and Gran Canaria. III. Rhodophyceae. Part I. Bangiales and Nemaliales. - Biol. Meddr 6 (6), 1-97.

Børgesen, F., 1929. The marine algae of Canary Islands specially from Teneriffe and Gran Canaria. III. Rhodophyceae. Part II. Cryptonemiales, Gigartinales and Rhodymeniales. - Biol. Meddr $8(1)$, $1-97$.

Børgesen, F., 1930. The marine algae of Canary Islands specially from Teneriffe and Gran Canaria. III. Rhodophyceae. Part III. Ceramiales. - Biol. Meddr 9 (1), 1-159.

Borgesen, F., 1938. Sur une collection d'algues marines recueillies à une profondeur remarquable près des Îles Canaries. - Revue algol. 11, 225-231.

Breeman, A. M., 1990. Expected effects of changing seawater temperatures on the geographic distribution of seaweed species. In: Expected effects of climatic change on marine coastal ecosystems. Ed. by J. J. Beukema, W. J. Wolff \& J. J. W. M. Brouns. Kluwer, Dordrecht, 69-76.

Feldmann, J., 1946. La flore marine des îles Atlantides. - Mém. Soc. Biogéogr. 8, 395-435.

Fredericq, S., Serrâo E. \& Norris, J. N., 1993. New records of marine red algae from the Azores. Arquipélago (Life and Earth Sciences) 10, 1-4.

Gil-Rodríguez, M. C. \& Afonso-Carrillo, J., 1980. Catálogo de las algas marinas bentónicas (Cyanophyta, Chlorophyta, Phaeophyta y Rhodophyta) para el Archipiélago Canario. Aula de Cultura de Tenerife, Santa Cruz de Tenerife, $47 \mathrm{pp}$.

Gil-Rodríguez, M. C., Haroun Tabraue, R., Afonso-Carrillo, J. \& Wildpret de la Torre, W., 1985. Adiciones al catálogo de algas marinas para el Archipiélago Canario II. - Vieraea 15, 101-112. 
Hanisak, M. D. \& Blair, S. M., 1988. The deep-water macroalgal community of the East Florida continental shelf (USA). - Helgoländer Meeresunters. 42, 133-163.

Hiscock, S. \& Maggs, C. A., 1984. Notes on the distribution and ecology of some new and interesting seaweeds from south-west Britain. - Br. phycol. J. 19, 73-87.

Hoek, C. van den, 1987. The possible significance of long-range dispersal for the biogeography of seaweeds. - Helgoländer Meeresunters. 41, 261-272.

Huvé, P. \& Huvé, H., 1977. Notes de nomenclature algale. I. - Le genre Halichrysis (J. Agardh 1851 emend $_{i}$. J. Agardh 1876) Schousboe mscr. in Bornet 1892 (Rhodyméniales, Rhodyméniacées). Bull. Soc, phycol. Fr. 22, 99-107.

Joly, A. B., 1957. Contribuiçâo ao conhecimento da flora ficologica marinha da Baía de Santos e arredores. - Bolm Fac. Filos, Ciênc, Univ. S Paulo 217, (Bot. 14) 1-196.

Kajimura, M., 1987. Deep-water flora of benthic marine algae in the Oki Islands, Sea of Japan. Botanica mar. 30, 373-385.

Lawson, G. W. \& John, D. M., 1987. The marine algae and coastal environment of tropical West Africa. - Nova Hedwigia (Beih.) 93, 1-415.

Littler, M. M., Littler, D. S., Blair, S. M. \& Norris, J. N., 1986. Deep-water plant communities from an uncharted seamount off San Salvador Island, Bahamas: distribution, abundance, and primary productivity. - Deep Sea Res. 33, 881-892.

Lïning, K., 1990. Seaweeds. Wiley, New York, 527 pp.

Maggs, C. A. \& Guiry, M. D., 1987. An atlantic population of Pikea californica (Dumontiaceae, Rhodophyta). - J. Phycol. 23, 170-176.

Norris, R. E., 1991. Some unusual marine red algae (Rhodophyta) from South Africa. - Phycologia 30, $582-596$.

Price, J. H., John, D. M. \& Lawson, G. W., 1986. Seaweeds of the western coast of tropical Africa and adjacent islands: a critical assessment. IV. Rhodophyta (Florideae) 1. Genera A-F. - Bull. Br. Mus. nat. Hist. (Bot.) 15, 1-122.

Prud'homme van Reine, W. F. 1988. Phytogeography of the Azores. - Helgoländer Meeresunters. 42, $165-185$.

Prud'homme van Reine, W. F. \& Hoek, C. van den, 1988. Biogeography of Capeverdean seaweeds. Cour. Forsch.-Inst. Senckenberg 105, 35-49.

Prud'homme van Reine, W. F. \& Hoek, C. van den, 1990. Biogeography of the Macaronesian seaweeds. - Cour. Forsch.-Inst. Senckenberg 129, 55-73.

Rietema, H., 1972. A morphological, developmental, and caryological study on the life history of Bryopsis halymeniae (Chlorophyceae). - Neth. J. Sea Res. 5, 445-457.

Rietema, H., 1975. Comparative investigations on the life-histories and reproduction of some species in the siphoneous green algal genera Bryopsis and Derbesia. Thesis, Univ. Groningen, $130 \mathrm{pp}$.

Sansón, M., Reyes, J. \& Afonso-Carrillo, J., 1991. Contribution to the seaweed flora of the Canary Islands: new records of Florideophyceae. - Botanica mar. 34, 527-536.

Schneider, C. W. \& Searles, R. B., 1973. North Carolina marine algae. II. New records and observations of the benthic offshore flora. - Phycologia 12, 201-211.

Schneider, C. W. \& Searles, R. B., 1991. Seaweeds of the southeastern United States, Cape Hatteras to Cape Canaveral. Duke Univ. Press, Durham, 533 pp.

Searles, R. B., 1984. Seaweed biogeography of the mid-Atlantic coast of the United States. Helgoländer Meeresunters. 38, 259-271.

Searles, R. B., 1987. Phenology and floristics of the seaweeds from the offshore waters or Georgia. Northeast Gulf Sci. 9, 99-108.

Searles, R. B. \& Schneider, C. W., 1987. Observations on the deep-water flora of Bermuda. Hydrobiologia 151-152, 261-266.

Taylor, W. R., 1942. Caribbean marine algae of the Allan Hancock Expedition, 1939. - Rep. Allan Hancock Atlant. Exped. 2, 1-193.

Taylor, W. R., 1945. Pacific marine algae of the Allan Hancock Expedition to the Galapagos Islands. Allan Hancock Pacif. Exped. 12, 1-528.

Taylor, W. R., 1960. Marine algae of the eastern tropical and subtropical coasts of the Americas. Univ. Michigan Press, Ann Arbor, 870 pp.

Vermeij, G. J., 1980. Biogeography and adaptation. Harvard Univ. Press, Cambridge, 332 pp.

Vermeij, G. J., 1987. Evolution and escalation. Princeton Univ. Press. Princeton, 527 pp. 
Vickers, A., 1897. Contribution à la flore algologique des Canaries. - Annls Sci. nat. (Bot.) 4 , 293-306.

Womersley, H. B. S., 1987. The marine benthic flora of southern Australia. Part. II. Govt. Print. Adelaide, $484 \mathrm{pp}$.

Wynne, M. J., 1986. A checklist of benthic marine algae of the tropical and subtropical western Atlantic. - Can. J. Bot. 64, 2239-2281. 